\title{
Honored Life Member Eugene M. Burreson March 25, 2009
}

\author{
Ryan Carnegie \\ Virginia Institute of Marine Science
}

CF Dungan

A Villalba

Kimberly S. Reece

Virginia Institute of Marine Science

Follow this and additional works at: https://scholarworks.wm.edu/vimsarticles

Part of the Marine Biology Commons

\section{Recommended Citation}

Carnegie, Ryan; Dungan, CF; Villalba, A; and Reece, Kimberly S., "Honored Life Member Eugene M. Burreson March 25, 2009" (2017). VIMS Articles. 305.

https://scholarworks.wm.edu/vimsarticles/305

This Article is brought to you for free and open access by the Virginia Institute of Marine Science at W\&M ScholarWorks. It has been accepted for inclusion in VIMS Articles by an authorized administrator of W\&M ScholarWorks. For more information, please contact scholarworks@wm.edu. 


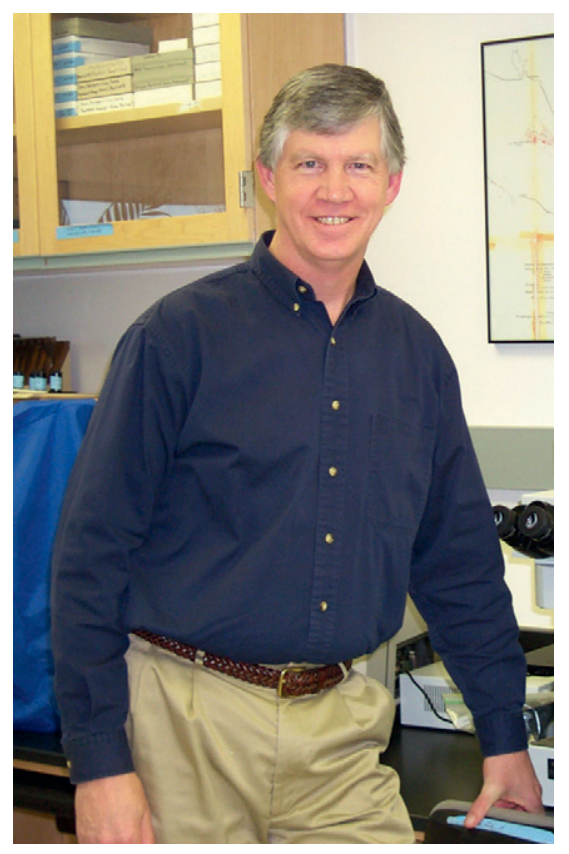

\section{HONORED LIFE MEMBER \\ Eugene M. Burreson}

March 25, 2009

Gene Burreson's arrival in the field of shellfish research was unplanned. A fish pathologist and parasitologist at the Virginia Institute of Marine Science (VIMS) from 1977, he was drawn into shellfish pathology in the early 1980s, working with the recently retired, but still active, Jay Andrews. Oyster mortality was rising during a time of drought and the institute needed to provide guidance to the state Secretary of Commerce and Resources and aquaculture community. Gene completely immersed himself in oyster disease research during the historic outbreak of MSX and dermo diseases in Chesapeake Bay beginning in 1986. That nearly total change in career focus, it should be noted, was not entirely Gene's choice - it was a directive from Frank Perkins, who was Director of VIMS at the time, and under pressure from the state government to respond to the oyster disease crisis. It was, however, serendipitous. A renewed U.S. federal emphasis on funding the study of oyster diseases through establishment of the Sea Grant Oyster Disease Research Program in 1989 led to a significant expansion of research in this area. Burreson and colleagues including Susan Ford capitalized on this support and developed comprehensive research programs. Over the subsequent quarter century, Gene produced an extensive body of work and numerous seminal papers. The paper he authored with Lisa Ragone Calvo, "Epizootiology of Perkinsus marinus disease of oysters in Chesapeake Bay, with emphasis on data since 1985," stands as a classic and remains one of the most highly cited papers in shellfish science (Burreson \& Ragone Calvo 1996). Gene has published nearly 80 peer-reviewed articles and book chapters to date on shellfish health, oyster disease ecology, nonnative oysters, parasite phylogenetics, and related topics, in addition to many others on fish parasites. Collectively, those achievements established him as one of the leading figures in the long history of shellish pathology.

Eugene M. Burreson was born in Seattle, WA, on July 25, 1944. He moved to Pendleton, OR, when he was four and lived there through his graduation from Pendleton High School in 1962. He attended Oregon State University from 1962 to 1965, majoring in Zoology, before transferring to Eastern Oregon College (now University) in La Grande, OR, for his final year. He married the former Susan Clark in 1966 and graduated from Eastern Oregon that year with a B.S. degree in biology. Almost immediately, Gene was off to Pensacola, FL, for Aviation Officer Candidate School, which ended with his commission as Ensign in the U.S. Navy in September 1966 (Gene received his commission from Admiral John S. McCain, Jr., father of current U.S. Senator John S. McCain III). He subsequently began flight training, and was eventually attached to Heavy Attack Squadron (VAH) 10 at Naval Air Station Whidbey Island, WA, flying aircraft carrier-based A-3 Skywarriors, which the Navy used for in-flight refueling. Gene made the first cruise on the carrier USS John F. Kennedy to the Mediterranean Sea. As the Viet Nam war wound down, the Navy released junior officers early, and Gene was honorably discharged in September 1969. He immediately entered graduate school in Zoology at the Oregon State University Hatfield Marine Science Center in Newport, OR, from which he earned an M.S. degree in 1973, and a Ph.D. in 1975 with a dissertation on blood parasites of marine fishes. After his graduation, Gene was hired by Normandeau Associates, Inc., as Project Director for Seabrook Nuclear Plant Environmental Studies in Hampton, NH. Gene joined VIMS in 1977 as Program Manager of Bureau of Land Management Middle Atlantic Outer Continental Shelf Environmental Studies.

DOI: $10.2983 / 035.036 .0101$ 
Gene's early work at VIMS focused largely on fish trypanosomes and marine leeches, the latter another area in which he is a global expert, and was conducted around training sessions for competitive triathlons and cycling events. With his entry into shellfish pathology, Gene pursued diverse research questions and collaborations, which resulted in many ambitious studies and important findings including understanding the epizootiology of Perkinsus marinus and environmental influences on dermo disease; diversity and phylogenetics of Perkinsus spp. and other haplosporidian parasites; haplosporidian ultrastructure and taxonomy; development of procedures for continuous in vitro culture of $P$. marinus; development of molecular diagnostics; breeding of oysters for resistance to MSX and dermo diseases; evaluation of nonnative oyster species in the Chesapeake Bay region; understanding the emergence of bonamiasis in Asian oysters in the southeastern United States; and host-parasite interactions. A paper linking Haplosporidium nelsoni to Crassostrea gigas from Asia (Burreson et al. 2000) is a seminal work, as are the numerous publications examining shellfish disease processes and ecology as well as those describing molecular diagnostic assays that have been used for detection of shellfish pathogens in laboratories around the world.

Gene is a leader in regional, national, and international management of shellfish health. He established the Shellfish Pathology Laboratory at VIMS as a key node in the network of regional laboratories ensuring the biosecurity of oyster and clam seed transport throughout the region, and provided regular guidance nationally to the U.S. Department of Agriculture, and locally to the Virginia Marine Resources Commission, on matters of shellfish health. He was designated a Reference Expert in 2000 by the Office International des Epizooties (known now as the World Organisation for Animal Health) for perkinsosis and haplosporidiosis, two globally significant classes of molluscan diseases, and remained in this role until 2010 when he retired. Burreson was a pioneer in bringing molecular biology into the field of shellfish disease diagnostics, and many of the molecular diagnostic assays that were developed by his laboratory in the early 1990s remain in use today. Providing support and training in molecular as well as microscopic diagnostics, and in shellfish pathology and parasitology more generally, were key outreach focuses of his program, and numerous investigators from Europe, Africa, South America, New Zealand, Australia, and the United States received skilled mentoring from Gene and training in his laboratory at VIMS. For his contributions to science and policy in the Chesapeake Bay region in particular, Gene received the Mathias Medal from Maryland Sea Grant, VA Sea Grant, and the Chesapeake Research Consortium in 2011. He had earlier received recognition as a Virginia Outstanding Scientist (2010) in addition to other awards for his teaching and advisory service at VIMS and the College of William \& Mary.

Gene has been an active, longtime member of the NSA, and has supported its meetings through his own regular participation as well as supporting presentations by numerous Burreson Laboratory students and staff. Similarly, he has provided consistent diligence and integrity as an expert reviewer for journals including the Journal of Shellfish Research (JSR), and has actively promoted submissions of first-quality research papers to JSR among his peers. With coauthors from diverse institutions, Gene has contributed 18 high-quality papers that were published in JSR. In all of his contributions to shellfish science and the NSA, Gene has been generous, gracious, and fair with his characteristically forthright and willing leadership.

As a shellfish scientist who is recognized worldwide for his achievements in the field, Gene Burreson has earned his National Shellfisheries Association Honored Life Member award many times over.

Ryan B. Carnegie

Research Associate Professor, Virginia Institute of Marine Science, College of William \& Mary, P.O. Box 1346, Gloucester Point, Virginia

Christopher F. Dungan

Research Scientist, Maryland Department of Natural Resources, Cooperative Oxford Laboratory, 904 S. Morris Street, Oxford, Maryland

Antonio Villalba

Senior Researcher, Centro de Investigacións Mariñas, Consellería do Mar, Xunta de Galicia, Spain

Kimberly S. Reece

Professor and Chair of the Department of Aquatic Health Sciences, Virginia Institute of Marine Science, College of William \& Mary, P.O. Box 1346, Gloucester Point, Virginia

\section{LITERATURE CITED}

Burreson, E. M. \& L. M. Ragone Calvo. 1996. Epizootiology of Perkinsus marinus disease of oysters in Chesapeake Bay, with emphasis on data since 1985. J. Shellfish Res. 15:17-34.
Burreson, E. M., N. A. Stokes \& C. S. Friedman. 2000. Increased virulence in an introduced pathogen: Haplosporidium nelsoni (MSX) in the eastern oyster Crassostrea virginica. J. Aquat. Anim. Health 12:1-8. 